\title{
Comparison of Herbal Agents with Sodium Hypochlorite as Root Canal Irrigant: A Systematic Review of In Vitro Studies
}

\author{
Kavalipurapu Venkata Teja, ${ }^{1}$ Krishnamachari Janani, ${ }^{2}$ Kumar Chandan Srivastava (D), ${ }^{3}$ \\ Deepti Shrivastava $\mathbb{D}^{\mathrm{D}},{ }^{4}$ Jerry Jose, ${ }^{1}$ Anand Marya $\mathbb{D}^{5},{ }^{5}$ and Mohmed Isaqali Karobari $\mathbb{D}^{1,6}$ \\ ${ }^{1}$ Department of Conservative Dentistry \& Endodontics, Saveetha Dental College \& Hospitals, \\ Saveetha Institute of Medical \& Technical Sciences, Saveetha University, Chennai, Tamil Nadu 600077, India \\ ${ }^{2}$ Department of Conservative Dentistry and Endodontics, SRM Dental College, SRM Institute of Science and Technology, \\ Ramapuram, Chennai-89, India \\ ${ }^{3}$ Oral Medicine \& Radiology, Department of Oral \& Maxillofacial Surgery \& Diagnostic Sciences, College of Dentistry, \\ Jouf University, Sakaka 72345, Saudi Arabia \\ ${ }^{4}$ Periodontics, Department of Preventive Dentistry, College of Dentistry, Jouf University, Sakaka 72345, Saudi Arabia \\ ${ }^{5}$ Department of Orthodontics, Faculty of Dentistry, University of Puthisastra, Phnom Penh 12211, Cambodia \\ ${ }^{6}$ Department of Restorative Dentistry \& Endodontics, Faculty of Dentistry, University of Puthisastra, \\ Phnom Penh 12211, Cambodia
}

Correspondence should be addressed to Kumar Chandan Srivastava; drkcs.omr@gmail.com and Mohmed Isaqali Karobari; dr.isaq@gmail.com

Received 9 October 2021; Accepted 10 November 2021; Published 25 November 2021

Academic Editor: Lidia Audrey Rocha Valadas

Copyright (C) 2021 Kavalipurapu Venkata Teja et al. This is an open access article distributed under the Creative Commons Attribution License, which permits unrestricted use, distribution, and reproduction in any medium, provided the original work is properly cited.

\begin{abstract}
During endodontic treatment, eliminating microorganisms from the root canals should be considered with utmost importance. Before filling the canal, every effort should be made to ensure optimal shaping and adequate disinfection of the root canal system. This systematic review aimed to compare the efficacy of herbal agents with sodium hypochlorite $(\mathrm{NaOCl})$ in reducing the microbial load while used as a root canal irrigant. The research question in the present study was to assess "Is there a significant difference in reducing microbial load comparing sodium hypochlorite $(\mathrm{NaOCl})$ and herbal agents." Electronic databases (PubMed, Scopus, and Web of Science) were searched from their start dates to November 2020 using strict inclusion and exclusion criteria and reviewed following PRISMA (Preferred Reporting Items for Systematic Reviews and Meta-Analyses) guidelines. Only in vitro studies comparing herbal agents with $\mathrm{NaOCl}$ regarding antimicrobial efficiency were included. Two reviewers independently assessed the included article. 825 articles were obtained from an electronic database. Twenty papers were included for review of the full text. Eleven papers were excluded because they did not meet the inclusion criteria. Finally, nine articles were included in the systematic review. The present systematic review was at the in vitro level; therefore, the result cannot translate the exact clinical conditions. This systematic review concludes that herbal agents cannot be used as a main irrigant for canal disinfection.
\end{abstract}

\section{Introduction}

The root canal of infected teeth is usually polymicrobial, existing as a biofilm. The ideal outcome of an endodontic treatment should target the elimination of microorganisms and their byproducts established within the root canal system [1]. Cases with persistent infection where the microorganisms are not completely eliminated need more attention as in the majority of cases it leads to reinfection [2]. To attain this, mechanical preparation of the root canal alone may not be sufficient. A disinfection regimen should emphasize optimal shaping such that the disinfectant reaches inaccessible areas such as anastomosis, isthmus, and the lateral canal [3]. 
An ideal irrigant should possess antimicrobial properties, an ability to dissolve the remnant necrotic pulp tissue, and should cause minimal irritation to the periapical tissue [4]. Different concentrations of sodium hypochlorite $(\mathrm{NaOCl})$ are commonly used as root canal irrigants as they possess the majority of the properties mentioned above for an ideal root canal irrigant. Its uniqueness among available root canal irrigants is that it can dissolve the necrotic and the remnant vital pulp tissue $[4,5]$. However, it irritates the periapical tissues when extruded beyond the apex, eventually leading to pain during root canal treatment.

In order to avoid complications associated with the usage of $\mathrm{NaOCl}$, many authors have suggested the usage of herbal agents as an alternative or as an adjunct to the conventional root canal irrigants [6,7]. Several herbal agents such as essential oil, triphala, green tea polyphenol, Morinda citrifolia, neem, tulsi, German chamomile, orange peel extract, and essential oregano oil have been studied to assess the antibacterial properties against the most resistant endodontic and periodontal pathogen [8-10]. Therefore, this systematic review was undertaken to investigate the effect of herbal irrigants in comparison with $\mathrm{NaOCl}$.

\section{Materials and Methods}

2.1. Rationale of Systematic Review. This systematic review aimed to assess the antimicrobial efficiency of herbal agents with sodium hypochlorite. This systematic review was conducted following the PRISMA 2020 (Preferred Reporting Items for Systematic Reviews and Meta-Analyses).

2.2. Objectives. The present systematic review included articles published on the conventional agent $(\mathrm{NaOCl})$ and herbal agents. The search was performed using multiple terms till November 2020.

2.3. PICOS Question. The research question was constructed based on the following:

Population: extracted human teeth infected with Enterococcus faecalis and Candida albicans

Intervention: all herbal irrigants

Comparison: $1-5.25 \%$ sodium hypochlorite $(\mathrm{NaOCl})$

Outcome: assessment of microbial reduction

Studies: in vitro studies

Principle: do the herbal irrigants differ in antimicrobial efficiency compared to $\mathrm{NaOCl}$

2.4. Search Strategy. Search terms related to root canal dentin, endodontic treatment, irrigants, herbal agents, and antimicrobial efficiency were searched for potential articles until November 2020. The databases used for the search were PubMed, Scopus, and Web of Science. The search strategy was modified based on the database used. A representative search strategy (used for PubMed) has been shown in Figure 1.

\subsection{Eligibility Criteria.}

Type of studies:

(i) In vitro studies and (ii) root canal irrigation performed on extracted teeth.

2.5.1. Inclusion Criteria. The herbal agents were compared with $\mathrm{NaOCl}$ for antimicrobial efficiency while performing an in vitro root canal treatment.

Full-text articles in English were selected.

The search was performed from different databases and duplicates were removed. Based on the eligibility criteria, the title and abstract of the article were carefully appraised to include the articles that matched the scope of the systematic review. Full-text articles were assessed for further analysis. Two independent reviewers performed the analysis as abovementioned and in the situation of any discrepancies, it was sought by the third reviewer.

\subsubsection{Exclusion Criteria.}

Animal studies and review articles

Full-text articles in languages other than English were excluded.

2.6. Data Extraction. Two independent reviewers performed the data extraction from the full text article included in the review. The outcome measure of this review compared the antimicrobial efficiency of herbal irrigants with $\mathrm{NaOCl}$. Variables such as sample size, choice of irrigants, volume and concentration of irrigant, choice of the needle, and the method of sample collection were assessed.

\section{Results}

A total of 825 articles were obtained from an electronic database, out of which 34 were duplicate records and hence were removed. Out of 791 articles, 771 articles were excluded following the title search. Twenty papers were included for the full-text review. Another eleven papers were excluded because they did not meet the inclusion criteria. Finally, nine articles were included in the systematic review (Table 1). A summary of article selection is presented as a flowchart, based on PRISMA guidelines (Figure 1). The general characteristics of the included article were tabulated separately for antimicrobial efficiency (Table 2).

3.1. Selection of Teeth and Sample Size. All the studies included for the review have chosen only single-rooted teeth for analysis with a sample size ranging from of 40 to 180 (Table 2). 


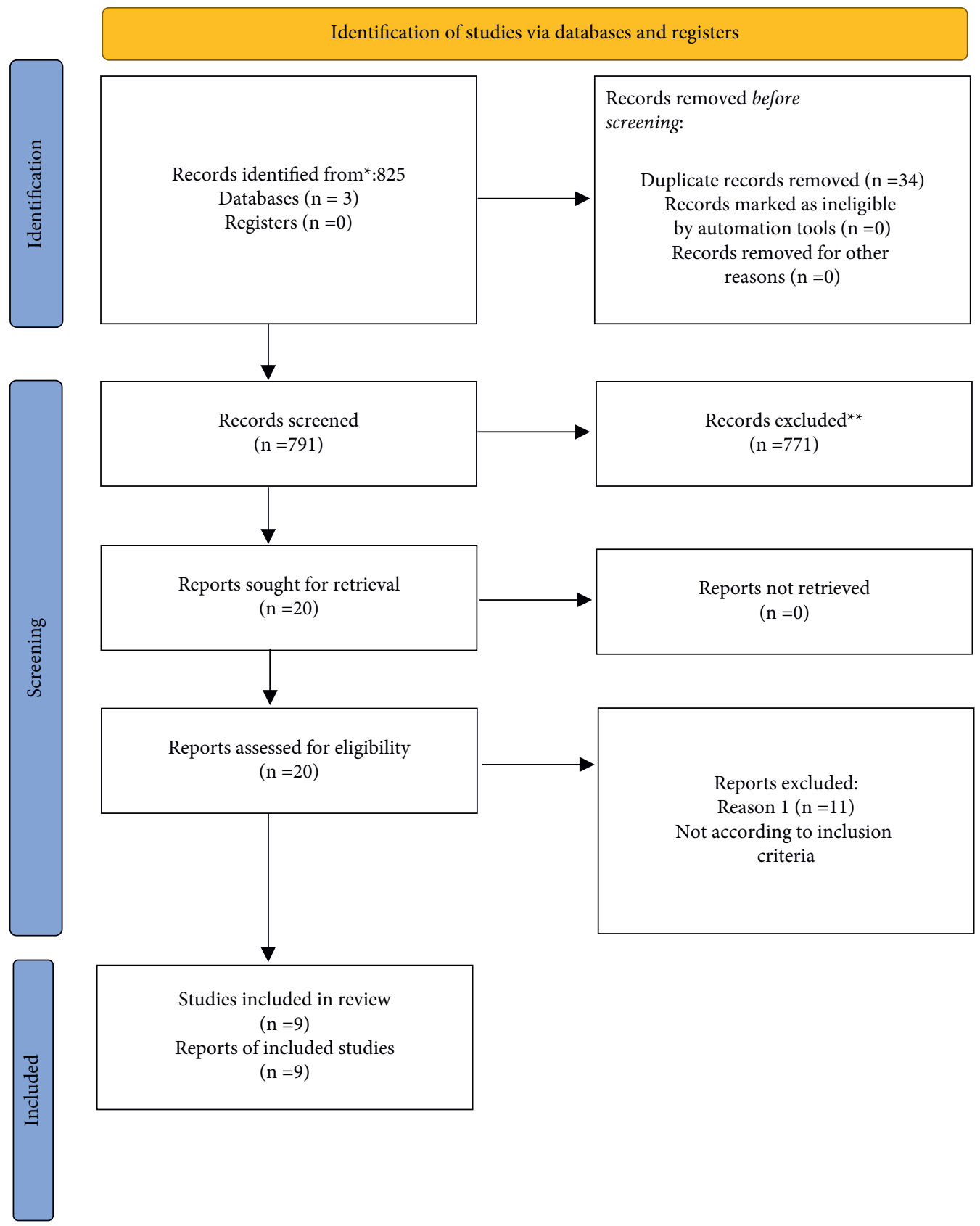

Figure 1: PRISMA flow diagram. ${ }^{*}$ Consider, if feasible to do so, reporting the number of records identified from each database or register searched (rather than the total number across all databases/registers). ${ }^{* *}$ If automation tools were used, indicate how many records were excluded by a human and how many were excluded by automation tools.

The risk of bias was high in all the papers for blinding and randomization as these details were not mentioned. All papers had a low risk of bias in data reporting; four out of nine studies reported low risk for standardization of protocol. The overall risk of bias was considered high.

\subsection{Antimicrobial Efficiency (Tables 3 and 4)}

3.2.1. Size of Apical Preparation. Four studies have performed the root canal preparation using a $\mathrm{K}$ file $[11,12,17,18]$. In the study performed by Rosaline et al. [14], the size of root canal preparation was not mentioned. Sharifian et al. [16], in their study, used low-speed round bur for canal preparation, whereas a rotary file system was used for the preparation of root canals in the remaining studies $[5,13,15]$.

3.2.2. Microbial Inoculation. Out of the nine studies included in the review, two studies did not mention the strain of Enterococcus faecalis used for their study [11, 18]. Two studies did not mention the adjusted suspension of colony forming units (CFU) of the strain $[16,17]$. 
TABle 1: Included article.

\begin{tabular}{|c|c|c|}
\hline $\begin{array}{l}\text { S. } \\
\text { No }\end{array}$ & Author & Title of included article \\
\hline 1 & Ok et al. [5] & Antibacterial and smear layer removal capabilities of oregano extract solution \\
\hline 2 & Pujar et al. [11] & $\begin{array}{l}\text { Comparison of antimicrobial efficacy of triphala, green tea polyphenols (GTP), and } 3 \% \text { of sodium } \\
\text { hypochlorite on Enterococcus faecalis biofilms formed on tooth substrate: in vitro }\end{array}$ \\
\hline 3 & Choudhary et al. [12] & Exploring the role of Morinda citrifolia and triphala juice in root canal irrigation: an ex vivo study \\
\hline 4 & $\begin{array}{l}\text { Sedigh-Shams et al. } \\
{[13]}\end{array}$ & $\begin{array}{l}\text { In vitro comparison of antimicrobial effects of sodium hypochlorite solution and Zataria multiflora } \\
\text { essential oil as irrigants in root canals contaminated with Candida albicans }\end{array}$ \\
\hline 5 & Rosaline et al. [14] & $\begin{array}{l}\text { Influence of various herbal irrigants as a final rinse on the adherence of Enterococcus faecalis by } \\
\text { fluorescence confocal laser scanning microscope }\end{array}$ \\
\hline 6 & $\begin{array}{l}\text { Gupta-Wadhwa et al. } \\
\qquad[15]\end{array}$ & $\begin{array}{l}\text { Comparative evaluation of the antimicrobial efficacy of three herbal irrigants in reducing intracanal } \\
\text { E. faecalis populations: an in vitro study }\end{array}$ \\
\hline 7 & Sharifian et al. [16] & Antibacterial substantivity of carvacrol and sodium hypochlorite in infected bovine root dentin \\
\hline 8 & Divia et al. [17] & $\begin{array}{l}\text { A comparative evaluation of Morinda citrifolia, green tea polyphenols, and triphala with } 5 \% \text { sodium } \\
\text { hypochlorite as an endodontic irrigant against Enterococcus faecalis: an in vitro study }\end{array}$ \\
\hline 9 & $\begin{array}{l}\text { Arvind Kumar et al. } \\
\qquad[18]\end{array}$ & $\begin{array}{l}\text { Comparative evaluation of antibacterial and smear layer removal efficacy of two different herbal irrigants: } \\
\text { an in vitro study }\end{array}$ \\
\hline
\end{tabular}

TABLE 2: General information of included article.

\begin{tabular}{|c|c|c|c|c|c|c|}
\hline $\begin{array}{l}\text { Author and } \\
\text { year }\end{array}$ & Selection of teeth & Sample size & Herbal irrigant & $\begin{array}{c}\text { Positive } \\
\text { control } \\
(\% \mathrm{NaOCl})\end{array}$ & $\begin{array}{l}\text { Negative } \\
\text { control }\end{array}$ & Other irrigants \\
\hline $\begin{array}{l}\text { OK et al. } 2015 \\
{[5]}\end{array}$ & $\begin{array}{c}\text { Permanent } \\
\text { maxillary central } \\
\text { incisors }\end{array}$ & $N=180$ & $\begin{array}{c}\text { Group 3: } 1 \% \text { oregano extract } \\
\text { solution, group } 4: 2 \% \\
\text { oregano extract solution, and } \\
\text { group5: } 5 \% \text { oregano extract } \\
\text { solution }\end{array}$ & $\begin{array}{l}\text { Group 6: } \\
5.25 \% \\
\mathrm{NaOCl}\end{array}$ & $\begin{array}{c}\text { Group 7: } \\
\text { sterile saline }\end{array}$ & $\begin{array}{c}\text { Group 1: } 17 \% \text { EDTA } \\
\text { and group2: } 2 \% \\
\text { chlorhexidine }\end{array}$ \\
\hline $\begin{array}{l}\text { Pujar et al. } \\
2011 \text { [11] }\end{array}$ & $\begin{array}{l}\text { Permanent } \\
\text { single rooted } \\
\text { premolar }\end{array}$ & $N=40$ & $\begin{array}{l}\text { Group } 1: 60 \mathrm{mg} / \mathrm{ml} \text { of } \\
\text { triphala in } 10 \% \mathrm{DMSO} \text { and } \\
\text { group 2: } 60 \mathrm{mg} / \mathrm{ml} \text { of green } \\
\text { tea polyphenol in } 10 \% \\
\text { DMSO }\end{array}$ & $\begin{array}{l}\text { Group 3: } 3 \% \\
\mathrm{NaOCl}\end{array}$ & $\begin{array}{c}\text { Group 4: } \\
\text { sterile saline }\end{array}$ & \\
\hline $\begin{array}{l}\text { Choudhary } \\
\text { et al. } 2018 \text { [12] }\end{array}$ & $\begin{array}{l}\text { Permanent } \\
\text { single rooted } \\
\text { teeth }\end{array}$ & $N=84$ & $\begin{array}{c}\text { Group } 1(N=16): \text { MCJ and } \\
\text { group2 }(N=16): \text { triphala } \\
\text { juice }\end{array}$ & $\begin{array}{l}\text { Group 3: } 1 \% \\
\mathrm{NaOCl}\end{array}$ & $\begin{array}{l}\text { Group 6: } \\
\text { sterile } \\
\text { distilled } \\
\text { water }\end{array}$ & $\begin{array}{l}\text { Group 4: } 2 \% \\
\text { chlorhexidine and } \\
\text { group 5: } \\
\text { preservative control } \\
\text { group }\end{array}$ \\
\hline $\begin{array}{l}\text { Sedigh-Shams } \\
\text { et al. } 2015 \text { [13] }\end{array}$ & $\begin{array}{l}\text { Permanent } \\
\text { mandibular } \\
\text { premolar }\end{array}$ & $N=60$ & $\begin{array}{l}\text { Group 1: a minimum } \\
\text { fungicidal concentration } \\
\text { (MFC) of } Z \text {. multiflora EO } \\
(1 \mathrm{mg} / \mathrm{ml} \text { ) of } 1: 1024 \text { and } \\
\text { group 2: twice the MFC of } \\
\text { Z. multiflora }\end{array}$ & $\begin{array}{l}\text { Group 3: } 1: \\
16 \mathrm{MFC} \text { of } \\
5 \% \mathrm{NaOCl} \\
(3 \mathrm{mg} / \mathrm{ml})\end{array}$ & $\begin{array}{l}\text { Group 4: } \\
\text { distilled } \\
\text { water }\end{array}$ & \\
\hline $\begin{array}{l}\text { Rosaline et al. } \\
2013 \text { [14] }\end{array}$ & $\begin{array}{l}\text { Permanent } \\
\text { single rooted } \\
\text { teeth }\end{array}$ & $N=50$ & $\begin{array}{c}\text { Group } 3: 1.25 \mathrm{mg} / \mathrm{ml} \text { of } \\
\text { Morinda citrifolia, group } 4 \text { : } \\
0.33 \mathrm{mg} / \mathrm{ml} \text { of Azadiracta } \\
\text { indica, and group } 5: \\
0.33 \mathrm{mg} / \mathrm{ml} \text { of green tea } \\
\text { polyphenol }\end{array}$ & $\begin{array}{l}\text { Group 2: } \\
5.25 \% \\
\mathrm{NaOCl}\end{array}$ & $\begin{array}{c}\text { Group 1: } \\
\text { sterile saline }\end{array}$ & \\
\hline $\begin{array}{l}\text { Gupta- } \\
\text { Wadhwa et al. } \\
2016[15]\end{array}$ & $\begin{array}{l}\text { Permanent } \\
\text { maxillary and } \\
\text { mandibular } \\
\text { single rooted } \\
\text { teeth }\end{array}$ & $N=40$ & $\begin{array}{l}\text { Group A: } 40 \% \text { O. sanctum, } \\
\text { group B: } 10 \% \text { S. aromaticum, } \\
\text { and group C: } 10 \% \\
\text { C. zeylanicum }\end{array}$ & $\begin{array}{l}\text { Group D: } \\
3 \% \mathrm{NaOCl}\end{array}$ & $\begin{array}{l}\text { Group E: } \\
\text { distilled } \\
\text { water }\end{array}$ & \\
\hline $\begin{array}{l}\text { Sharifian et al. } \\
2009 \text { [16] }\end{array}$ & Bovine incisors & $N=120$ & Group 2: carvacrol 10\% & $\begin{array}{l}\text { Group 1: } \\
\mathrm{NaOCl} \\
5.25 \%\end{array}$ & $\begin{array}{l}\text { Group 3: } \\
\text { infected } \\
\text { dentin tube }\end{array}$ & $\begin{array}{l}\text { Group 4: sterile } \\
\text { dentin tube }\end{array}$ \\
\hline
\end{tabular}


TABle 2: Continued.

\begin{tabular}{|c|c|c|c|c|c|c|}
\hline $\begin{array}{l}\text { Author and } \\
\text { year }\end{array}$ & Selection of teeth & Sample size & Herbal irrigant & $\begin{array}{c}\text { Positive } \\
\text { control } \\
(\% \mathrm{NaOCl}) \\
\end{array}$ & $\begin{array}{l}\text { Negative } \\
\text { control }\end{array}$ & Other irrigants \\
\hline $\begin{array}{l}\text { Divia et al. } \\
2018 \text { [17] }\end{array}$ & $\begin{array}{c}\text { Permanent } \\
\text { premolar teeth }\end{array}$ & $N=60$ & $\begin{array}{c}\text { Group 3: Morinda citrifolia } \\
(64 \mathrm{mg} / \mathrm{ml} \text { in } 10 \% \text { DMSO), } \\
\text { group 4: triphala ( } 64 \mathrm{mg} / \mathrm{ml} \\
\text { in } 10 \% \text { DMSO), and group 5: } \\
\text { green tea polyphenols } \\
(64 \mathrm{mg} / \mathrm{ml} \text { in } 10 \% \text { DMSO })\end{array}$ & $\begin{array}{c}\text { Group 2: } 5 \% \\
\mathrm{NaOCl}\end{array}$ & $\begin{array}{l}\text { Group 1: } \\
\text { distilled } \\
\text { water }\end{array}$ & \\
\hline $\begin{array}{l}\text { Kumar et al. } \\
2018[18]\end{array}$ & $\begin{array}{l}\text { Maxillary central } \\
\text { incisors }\end{array}$ & $\begin{array}{l}\quad N=120 \\
\text { antimicrobial efficacy } \\
(N=60) \text { and smear } \\
\text { layer removal efficacy } \\
(N=60)\end{array}$ & $\begin{array}{l}\text { Group IB: } 25 \% \text { neem extract } \\
(N=20) \text { and group IC: } 25 \% \\
\text { tulsi Extract }(N=20)\end{array}$ & $\begin{array}{l}\text { Group IA: } \\
3 \% \mathrm{NaOCl} \\
(N=20)\end{array}$ & & \\
\hline
\end{tabular}

TABLE 3: Methodology assessment.

\begin{tabular}{|c|c|c|c|c|c|c|c|}
\hline Author and year & $\begin{array}{c}\text { Microbial } \\
\text { inoculation }\end{array}$ & $\begin{array}{l}\text { Root canal } \\
\text { preparation } \\
\text { (instruments } \\
\text { used and size of } \\
\text { preparation) }\end{array}$ & Irrigation protocol & $\begin{array}{l}\text { Volume of } \\
\text { irrigant }\end{array}$ & $\begin{array}{l}\text { Time of } \\
\text { irrigation }\end{array}$ & $\begin{array}{l}\text { Needle used } \\
\text { for } \\
\text { irrigation }\end{array}$ & $\begin{array}{l}\text { Irrigant } \\
\text { activation } \\
\text { devices } \\
\text { used }\end{array}$ \\
\hline Ok et al. 2015 [5] & $\begin{array}{l}\text { E. faecalis (ATCC } \\
\text { 29212) cultured in } \\
\text { a BHI agar } \\
\text { suspension } \\
\text { adjusted to } 1 \times 10^{8} \\
\text { CFU }\end{array}$ & $\begin{array}{l}\text { ProTaper NiTi } \\
\text { rotary files } \\
30.06 \% \text { taper }\end{array}$ & $\begin{array}{l}\text { No protocol } \\
\text { mentioned }\end{array}$ & $\begin{array}{c}6 \mathrm{ml} \text { of each } \\
\text { irrigant }\end{array}$ & $2 \min$ & $\begin{array}{c}\text { Not } \\
\text { mentioned } \\
\text { in the study }\end{array}$ & Nil \\
\hline $\begin{array}{l}\text { Pujar et al. } 2011 \\
\text { [11] }\end{array}$ & $\begin{array}{l}\text { E. faecalis cultured } \\
\text { in a BHI agar } \\
\text { (strain not } \\
\text { mentioned) }\end{array}$ & $\begin{array}{l}\text { Step back upto } \\
40 \mathrm{~K} \text { file }\end{array}$ & $\begin{array}{l}\text { No protocol } \\
\text { mentioned }\end{array}$ & $\begin{array}{c}3 \mathrm{ml} \text { of each } \\
\text { irrigant }\end{array}$ & 10 mins & $\begin{array}{c}\text { Not } \\
\text { mentioned } \\
\text { in the study }\end{array}$ & Nil \\
\hline $\begin{array}{l}\text { Choudhary et al. } \\
2018 \text { [12] }\end{array}$ & $\begin{array}{l}\text { E. faecalis (MTCC } \\
\text { 2729) and } \\
\text { C. albicans } \\
\text { (MTCC 1637) in a } \\
\text { BHI agar is } \\
\text { inoculated in } 5 \mathrm{~mL} \\
\text { of suspension to } \\
\text { obtain } 1: 1010 \\
\text { dilution }\end{array}$ & $\begin{array}{l}\text { Step back upto } \\
40 \mathrm{~K} \text { file }\end{array}$ & $\begin{array}{l}\text { During canal } \\
\text { preparation, } 3 \mathrm{~mL} \text { of } \\
\text { respective irrigant was } \\
\text { used for } 15 \mathrm{mins} \text { after } \\
\text { enlargement, } 2 \mathrm{~mL} \text { of } \\
\text { irrigant solution was } \\
\text { used to rinse debris in } \\
\text { the canals for another } \\
5 \mathrm{~min} \text {. Sterile normal } \\
\text { saline }(2 \mathrm{~mL}) \text { was used }\end{array}$ & $\begin{array}{c}5 \mathrm{ml} \text { of each } \\
\text { irrigant }\end{array}$ & 20 mins & $\begin{array}{l}\text { 30-gauge } \\
\text { needle }\end{array}$ & Nil \\
\hline $\begin{array}{l}\text { Sedigh-Shams } \\
\text { et al. } 2015 \text { [13] }\end{array}$ & $\begin{array}{l}\text { C. albicans in } \\
\text { sabouraud } \\
\text { dextrose agar } \\
\text { suspensions } \\
\text { adjusted to } \\
1.5 \times 10^{8} \mathrm{CFU}\end{array}$ & $\begin{array}{l}\text { ProTaper NiTi } \\
\text { rotary files } \\
30.06 \% \text { taper }\end{array}$ & $\begin{array}{l}\text { as a final rinse } \\
\text { During canal } \\
\text { preparation, } 10 \mathrm{ml} \text { of } \\
\text { respective irrigants } \\
\text { were used. Groups } 1 \\
\text { and } 2 \text { were irrigated } \\
\text { with } 2 \mathrm{ml} \text { of sterile } \\
\text { distilled water to } \\
\text { remove the remaining } \\
Z \text {. multiflora EO. } \\
\text { Group } 3 \text { were irrigated } \\
\text { with } 2 \text { ml of } 4 \% \text { sterile } \\
\text { sodium thiosulfate } \\
\text { solution to neutralize } \\
\text { the remaining } \mathrm{NaOCl}\end{array}$ & $\begin{array}{l}10 \mathrm{ml} \text { of each } \\
\text { irrigant }\end{array}$ & $12-14$ mins & $\begin{array}{l}\text { 27-gauge } \\
\text { needle }\end{array}$ & Nil \\
\hline
\end{tabular}


TABle 3: Continued.

\begin{tabular}{|c|c|c|c|c|c|c|c|}
\hline Author and year & $\begin{array}{c}\text { Microbial } \\
\text { inoculation }\end{array}$ & $\begin{array}{l}\text { Root canal } \\
\text { preparation } \\
\text { (instruments } \\
\text { used and size of } \\
\text { preparation) }\end{array}$ & Irrigation protocol & $\begin{array}{l}\text { Volume of } \\
\text { irrigant }\end{array}$ & $\begin{array}{l}\text { Time of } \\
\text { irrigation }\end{array}$ & $\begin{array}{l}\text { Needle used } \\
\text { for } \\
\text { irrigation }\end{array}$ & $\begin{array}{l}\text { Irrigant } \\
\text { activation } \\
\text { devices } \\
\text { used }\end{array}$ \\
\hline $\begin{array}{l}\text { Rosaline et al. } \\
2013 \text { [14] }\end{array}$ & $\begin{array}{l}\text { E. faecalis (ATCC } \\
\text { 29212) cultured in } \\
\text { tryptone bile X- } \\
\text { glucuronide agar } \\
\text { suspensions } \\
\text { adjusted to } 1 \times 10^{6}\end{array}$ & $\begin{array}{l}\text { Not mentioned } \\
\text { in the study }\end{array}$ & $\begin{array}{l}\text { All the specimens were } \\
\text { treated with } 5.25 \% \\
\mathrm{NaOCl} \text { for } 30 \mathrm{~min} \\
\text { followed by } 5 \mathrm{mmol} / \mathrm{L} \\
17 \% \text { EDTA for } 5 \mathrm{mins} \text {. } \\
\text { After which, the final }\end{array}$ & $\begin{array}{l}\text { Not } \\
\text { mentioned } \\
\text { about the } \\
\text { volume of } \\
\text { final rinse }\end{array}$ & $\begin{array}{c}\text { Final } \\
\text { irrigation } \\
\text { for } 30 \mathrm{mins}\end{array}$ & $\begin{array}{l}\text { Not } \\
\text { mentioned } \\
\text { in study }\end{array}$ & Nil \\
\hline $\begin{array}{l}\text { Gupta-Wadhwa } \\
\text { et al. } 2016 \text { [15] }\end{array}$ & $\begin{array}{c}\text { E. faecalis (ATCC } \\
29212 \text { ) } \\
\text { suspensions } \\
\text { adjusted to } \\
1.5 \times 10^{8} \mathrm{CFU}\end{array}$ & $\begin{array}{l}\text { ProTaper NiTi } \\
\text { rotary files } \\
30.06 \% \text { taper }\end{array}$ & $\begin{array}{l}\text { irrigants were used } \\
\text { Initially, } 2 \mathrm{~mL} \text { of } \\
\text { experimental extract } \\
\text { for } 30 \mathrm{~s} \text {; during } \\
\text { instrumentation, the } \\
\text { canal was irrigated } \\
\text { with } 2 \mathrm{~mL} \text { of the tested } \\
\text { extract. After } \\
\text { instrumentation } \\
\text { experimental, extract } \\
\text { was left undisturbed } \\
\text { for } 60 \mathrm{~s} \text { and then } \\
\text { finally irrigated with } \\
2 \text { mL of } 3 \% \mathrm{NaOCl} \\
\text { followed by } 5 \mathrm{~mL} \text { of } \\
17 \% \text { EDTA for } 1 \mathrm{~min} \\
\text { and again with } 2 \mathrm{~mL} \text { of } \\
\text { experimental extract }\end{array}$ & $\begin{array}{c}20 \mathrm{ml} \text { used in } \\
\text { each canal }\end{array}$ & $\begin{array}{l}\text { 6mins } 30 \mathrm{~s} \\
\text { approx. }\end{array}$ & $\begin{array}{l}\text { 30-gauge } \\
\text { needle }\end{array}$ & Nil \\
\hline $\begin{array}{l}\text { Sharifian et al. } \\
2009 \text { [16] }\end{array}$ & $\begin{array}{c}\text { E. faecalis (ATCC } \\
\text { 29212) }\end{array}$ & $\begin{array}{l}\text { Specimens } \\
\text { enlarged low- } \\
\text { speed round } \\
\text { burs of ISO sizes } \\
\text { 025, 027, 029, } \\
031 \text {, and } 033\end{array}$ & $\begin{array}{l}\text { No protocol was } \\
\text { mentioned }\end{array}$ & $\begin{array}{c}\text { Not } \\
\text { mentioned }\end{array}$ & $\begin{array}{l}20 \text { mins } \\
\text { contact } \\
\text { time of } \\
\text { irrigant }\end{array}$ & $\begin{array}{c}\text { Not } \\
\text { mentioned }\end{array}$ & Nil \\
\hline $\begin{array}{l}\text { Divia et al. } 2018 \\
\text { [17] }\end{array}$ & $\begin{array}{c}\text { E. faecalis (ATCC } \\
\text { 29212) }\end{array}$ & $\begin{array}{l}\text { Step back upto } \\
50 \mathrm{k} \text { file }\end{array}$ & $\begin{array}{l}\text { No protocol was } \\
\text { mentioned }\end{array}$ & $\begin{array}{l}\text { Not } \\
\text { mentioned }\end{array}$ & $\begin{array}{c}\text { Not } \\
\text { mentioned }\end{array}$ & $\begin{array}{c}\text { Not } \\
\text { mentioned }\end{array}$ & Nil \\
\hline $\begin{array}{l}\text { Kumar et al. } 2018 \\
{[18]}\end{array}$ & $\begin{array}{l}\text { E. faecalis (strain } \\
\text { not mentioned) }\end{array}$ & $\begin{array}{l}\text { Step back up to } \\
\text { 30K size }\end{array}$ & $\begin{array}{l}\text { No protocol was } \\
\text { mentioned }\end{array}$ & $\begin{array}{l}6 \mathrm{ml} \text { of } \\
\text { irrigants }\end{array}$ & $\begin{array}{l}\text { At the rate } \\
\text { of } 2 \mathrm{ml} / 15 \\
\text { seconds }\end{array}$ & $\begin{array}{l}\text { 25-gauge } \\
\text { needle }\end{array}$ & Nil \\
\hline
\end{tabular}

TABLe 4: Methodology assessment.

\begin{tabular}{|c|c|c|c|c|}
\hline Author and year & Sample collection & Culture plate & Assessment method & Statistical analysis performed \\
\hline Ok et al. 2015 [5] & $\begin{array}{l}\text { The sample was collected } \\
\text { in an Eppendorf tube } \\
\text { containing BHI broth }\end{array}$ & $\begin{array}{l}\text { BHI and blood } \\
\text { agar broth }\end{array}$ & Colony forming units & $\begin{array}{c}\text { Kruskal-Wallis test and mann-Whitney } U \\
\text { test }\end{array}$ \\
\hline $\begin{array}{l}\text { Pujar et al. } 2011 \\
{[11]}\end{array}$ & $\begin{array}{l}\text { The sample was scraped } \\
\text { from the root canal }\end{array}$ & BHI broth & Colony forming units & $\begin{array}{c}\text { One-way analysis of variance with post hoc } \\
\text { tukey tests }\end{array}$ \\
\hline $\begin{array}{l}\text { Choudhary et al. } \\
2018[12]\end{array}$ & $\begin{array}{l}\text { Sterile paper points were } \\
\text { inserted into the canal to } \\
\text { collect samples }\end{array}$ & $\begin{array}{l}\text { BHI agar plate and } \\
\text { SDA }\end{array}$ & Colony forming units & $\begin{array}{l}\text { Intragroup comparison of Friedman's two- } \\
\text { way analysis of variance by ranks and post } \\
\text { hoc Wilcoxon signed-rank test. Intergroup } \\
\text { comparison of Kruskal-Wallis test }\end{array}$ \\
\hline $\begin{array}{l}\text { Sedigh-Shams } \\
\text { et al. } 2015 \text { [13] }\end{array}$ & $\begin{array}{l}\text { Sterile paper points were } \\
\text { inserted into the canal to } \\
\text { collect samples }\end{array}$ & SDA agar plate & Colony forming units & Kruskal-Wallis and Mann-Whitney tests \\
\hline $\begin{array}{l}\text { Rosaline et al. } \\
2013 \text { [14] }\end{array}$ & $\begin{array}{l}\text { Dentin specimen was } \\
\text { spread on the slide. } \\
\text { Stained with BacLight }\end{array}$ & $\begin{array}{l}\text { Confocal laser } \\
\text { scanning } \\
\text { microscopy }\end{array}$ & $\begin{array}{l}\text { Bacteria counted by a } \\
\text { manual digital counter }\end{array}$ & One-way ANOVA \\
\hline
\end{tabular}


TABLE 4: Continued.

\begin{tabular}{|c|c|c|c|c|}
\hline Auth & ection & ate & Assessment method & \\
\hline $\begin{array}{l}\text { Gupta-Wadhwa } \\
\text { et al. } 2016[15]\end{array}$ & $\begin{array}{l}\text { Paper point was used to } \\
\text { the collect sample }\end{array}$ & $\begin{array}{l}\text { PCR BHI agar } \\
\text { plate }\end{array}$ & $\begin{array}{l}\text { acterial DNA isolation } \\
\text { and detection colony } \\
\text { forming units }\end{array}$ & $\begin{array}{r}\text { Student's } t \text {-te } \\
\text { Kruskal-Walli }\end{array}$ \\
\hline & $\begin{array}{l}\text { Dentin chips were } \\
\text { collected from the bur }\end{array}$ & $\mathrm{BHI}$ agar plate & Colony forming units & One-way analys \\
\hline Divia et al. 2018 & Not $n$ & $\begin{array}{l}\text { Not mentio } \\
\text { the stuc }\end{array}$ & & Kruskal-Wallis \\
\hline $\begin{array}{l}\text { Kumar et al. } \\
2018[18]\end{array}$ & $\begin{array}{l}\text { Sample collected using } \mathrm{H} \\
\text { file }\end{array}$ & $\begin{array}{c}\text { Real time } \\
\text { quantitative PCR }\end{array}$ & 3acterial DNA isolation & $\begin{array}{c}\text { One-way analysis of variance with post hoc } \\
\text { test (Tukey) }\end{array}$ \\
\hline
\end{tabular}

3.2.3. Irrigation Protocol. Five studies did not mention the protocol followed for root canal irrigation [5, 11, 16-18]. The remaining four studies mentioned the irrigation protocol which they followed in their studies [12-15].

3.2.4. Volume of Irrigant and Time of Irrigation. The other important aspect for a successful outcome of disinfection is the volume of the irrigant used and its time of contact within the root canal system. Out of included studies, two studies have not mentioned the volume of the irrigant used $[14,16,17]$. Concerning the contact time of the irrigant, no details were mentioned in the study conducted by Divia et al. 2018 [17].

3.2.5. Choice of Irrigation Needle and Irrigant Activation. The choice of needle used for root canal disinfection has a considerable impact on the penetration depth of the irrigant, irrigant flow pattern, and shear stress exerted on the canal wall. Five studies have not mentioned the gauge of the needle and tip design $[5,11,14,16,17]$. Two studies have performed irrigation with a 30 -gauge needle $[12,15]$. Sedigh-Shams et al. [13] used a 27-gauge needle, whereas Arvind Kumar et al. [18] used a 25-gauge needle. However, the remaining studies have not mentioned the choice of the needle. Among the included articles, none of the studies has mentioned the agitation device used for disinfection.

3.2.6. Sample Collection. Most of the included articles used sterile paper points to collect the samples from the canal. Out of all the studies, only one study has not mentioned the sample collection method [17]. In the study by Kumar et al. [18], an $\mathrm{H}$ file was used to collect the sample from the root canal.

3.2.7. Culture Method. Rosaline et al. [14] used confocal laser scanning microscopy to evaluate the remaining bacterial adhesion to root dentin. On the other hand, Gupta-Wadhwa et al. [15] and Kumar et al. [18] used polymerase chain reaction (PCR). Remaining studies performed CFU's assessment to assess antimicrobial efficiency. The assessment of antimicrobial activity is mentioned in Table 5.

3.3. Risk of Bias. Cochrane criteria for risk of bias were modified according to in vitro studies by evaluating the domain about present reviews such as randomization, standardized operator protocol, blinding, and data reporting. Blinding in these studies implies blinding of the evaluator. The risk of bias was scored as low when the details of the parameters as mentioned earlier were mentioned with no ambiguity, but when there was ambiguity, they were scored as unclear. When no details were mentioned, it was scored as high.

Cochrane criteria were modified by taking into consideration a few parameters for the quality assessment [19]. For the antimicrobial studies, all the included articles reported about the type and number of canals. None of the studies mentioned whether a single operator performed all the experimental procedures. Four studies reported a high risk of bias as they did not mention the volume of the irrigant used, and five studies did not mention the type of needle used for the irrigation-none of the studies mentioned the blinding of the evaluator (Table 6).

The authors of this review take the standpoint that all the study details need to be mentioned and focused on keeping the risk of bias low. Furthermore, the authors of this review believe that the experiments were performed according to a standardized protocol but might not have reported the intricate details since these are in vitro studies.

\section{Discussion}

It is well documented that primary endodontic infections are dominated by obligate anaerobic microorganisms detached from the root canal system compared to facultative bacteria [20]. It can be substantiated by the ability of flora to colonize predominantly into the main canal and least colonization into the complex areas of the root canal system [21]. Once established within the root canal system, these bacteria are difficult to eradicate as they can survive in extreme conditions. Attaining three-dimensional disinfection becomes more complex, predominantly when the microorganisms get colonized into intercanal communication, fins, cul-de-sac, and isthmus [22]. Mechanical enlargement of the root canal alone cannot eradicate the microorganisms from the root canal system, which eventually emphasizes disinfection.

4.1. Call for Action. Considering the disinfection for the root canal system, various factors need to be taken into account. It depends on various factors such as endodontic microbiota, access cavity design, canal preparation technique, property of the agents used for canal disinfection, the volume and 
TABLE 5: The results of the assessment.

\begin{tabular}{|c|c|c|}
\hline Author and year & Reduction in bacterial load & Outcome \\
\hline Ok et al. 2015 [5] & $\begin{array}{c}\text { Mean of the } \log _{10} \text { CFU and SD: } 1 \% \text { oregano } \\
\text { extract }-1.404 \pm 1.803 \mathrm{CFU} / \mathrm{ml} \text { and } 5.25 \% \\
\mathrm{NaOCl}-2.308 \pm 1.739 \mathrm{CFU} / \mathrm{ml}\end{array}$ & $\begin{array}{l}\text { 1\% oregano extract solution showed a similar result } \\
\text { to } 5.25 \% \mathrm{NaOCl}\end{array}$ \\
\hline $\begin{array}{l}\text { Pujar et al. } 2011 \\
\text { [11] }\end{array}$ & $\begin{array}{l}\text { Mean of the } \log _{10} \mathrm{CFU} \text { and SD: triphala } 2.3 \pm 0.59 \times 104 \mathrm{CFU} / \\
\text { ml, green tea } 3.8 \pm 0.79 \times 104 \mathrm{CFU} / \mathrm{ml} \text {, and } 3 \% \mathrm{NaOCl} 0.00\end{array}$ & $\begin{array}{c}\text { Hypochlorite exhibited the maximum bacterial } \\
\text { inhibition compared to triphala and green tea } \\
\text { extract }\end{array}$ \\
\hline $\begin{array}{l}\text { Choudhary et al. } \\
2018 \text { [12] }\end{array}$ & $\begin{array}{c}\text { Mean of the } \log _{10} \text { CFU and SD: Morinda citrifolia } 3.51 \pm 0.29 \\
\text { triphala } 3.37 \pm 0.56 \text {, and } 1 \% \mathrm{NaOCl} 1.43 \pm 0.53\end{array}$ & $\begin{array}{l}\text { Compared to } 1 \% \mathrm{NaOCl}, \text { morinda and triphala } \\
\text { showed reduced effectiveness }\end{array}$ \\
\hline $\begin{array}{l}\text { Sedigh-Shams } \\
\text { et al. } 2015[13]\end{array}$ & $\begin{array}{c}\text { \% bacterial CFU reduction: } Z \text {. multiflora (2 times of MFC)- } \\
200,000 \pm 05 \% \text { NaOCl- } 200,000 \pm 0 \text { Z. multiflora } \\
\text { MFC- } 199,540 \pm 313\end{array}$ & $\begin{array}{l}\text { Both } Z \text {. multiflora ( } 2 \text { times of MFC) and } 5 \% \mathrm{NaOCl} \\
\text { showed similar antimicrobial efficiency }\end{array}$ \\
\hline $\begin{array}{l}\text { Rosaline et al. } \\
2013 \text { [14] }\end{array}$ & $\begin{array}{c}\text { \% remaining bacterial adhesion to dentin: } A \\
9.30 \% \text { and } 5.25 \%, \mathrm{NaOCl} 12.50 \% \text {, green te } \\
\text { Morinda citrifolia } 44.20 \%\end{array}$ & $\begin{array}{l}\text { Compared to } 5.25 \% \mathrm{NaOCl}, \text { Azadiracta indica } \\
\text { showed reduced bacterial adherence }\end{array}$ \\
\hline $\begin{array}{l}\text { Gupta-Wadhwa } \\
\text { et al. } 2016[15]\end{array}$ & $\begin{array}{l}\text { Ocimum sanctum- } 2.65 \times 10^{5}, \text { Cinnamomum } \\
\text { zeylanicum }-1.535 \times 10^{5}, \text { Syzygium aromaticum }-1.425 \times 10^{5}, \\
\text { and } 3 \% \mathrm{NaOCl}-1.402 \times 10^{4}\end{array}$ & $\begin{array}{l}\text { Compared to other herbal agents, } 3 \% \mathrm{NaOCl} \\
\text { showed better antimicrobial efficiency }\end{array}$ \\
\hline $\begin{array}{l}\text { Sharifian et al. } \\
2009[16]\end{array}$ & $\begin{array}{c}\text { Substantivity was assessed over a period of } 28 \text { days. CFU } \\
\text { reduction (\%) } \pm \text { SD: carvacrol } 99.3 \pm 1.545 .25 \% \text { and } \mathrm{NaOCl} \\
99.98 \pm 0.04\end{array}$ & $\begin{array}{c}5.25 \% \mathrm{NaOCl} \text { showed significantly better results } \\
\text { than carvacrol }\end{array}$ \\
\hline $\begin{array}{l}\text { Divia et al. } 2018 \\
\text { [17] }\end{array}$ & $\begin{array}{c}\text { CFU reduction } \pm \text { SD: } 5 \% \mathrm{NaOCl} 0.67 \pm 0.78 \text {, Morinda citrifolia } \\
158.17 \pm 19.83 \text {, triphala } 15.92 \pm 2.87 \text {, and green tea polyphenol } \\
56.67 \pm 7.18\end{array}$ & $\begin{array}{l}\mathrm{NaOCl} \text { showed the maximum antibacterial effect, } \\
\text { followed by triphala, green tea polyphenol, and least } \\
\text { was Morinda citrifolia }\end{array}$ \\
\hline $\begin{array}{l}\text { Kumar et al. } 2018 \\
{[18]}\end{array}$ & $\begin{array}{c}\text { PCR mean value of antimicrobial efficiency: } 3 \% \mathrm{NaOCl}-34.20 \text {, } \\
\text { neem-33.93, and tulsi-31.86 }\end{array}$ & $\begin{array}{l}\mathrm{NaOCl} \text { showed the maximum antibacterial activity, } \\
\text { followed by neem leaf extract. The least effect was } \\
\text { seen with tulsi }\end{array}$ \\
\hline
\end{tabular}

TABLE 6: Risk of bias assessment.

\begin{tabular}{|c|c|c|c|c|c|}
\hline Author and year & Randomization & $\begin{array}{c}\text { Allocation } \\
\text { concealment }\end{array}$ & Blinding & Standardized preparation & $\begin{array}{c}\text { Reporting } \\
\text { data }\end{array}$ \\
\hline Ok et al. 2015 [5] & $\begin{array}{l}\text { Unclear (teeth were } \\
\text { randomly divided) }\end{array}$ & $\begin{array}{l}\text { High (not } \\
\text { mentioned) }\end{array}$ & $\begin{array}{l}\text { High (not } \\
\text { mentioned) }\end{array}$ & ( & Low \\
\hline $\begin{array}{l}\text { Pujar et al. } 2011 \\
\text { [11] }\end{array}$ & $\begin{array}{l}\text { Unclear (the samples } \\
\text { were divided.) }\end{array}$ & $\begin{array}{l}\text { High (not } \\
\text { mentioned) }\end{array}$ & $\begin{array}{l}\text { High (not } \\
\text { mentioned) }\end{array}$ & $\begin{array}{l}\text { High (strain not mentioned, irrigation } \\
\text { protocol not mentioned, also the type of needle } \\
\text { used) }\end{array}$ & Low \\
\hline $\begin{array}{l}\text { Choudhary et al. } \\
2018 \text { [12] }\end{array}$ & Low & $\begin{array}{l}\text { High (not } \\
\text { mentioned) }\end{array}$ & $\begin{array}{l}\text { High (not } \\
\text { mentioned) }\end{array}$ & ( & Low \\
\hline $\begin{array}{l}\text { Sedigh-Shams } \\
\text { et al. } 2015 \text { [13] }\end{array}$ & High (not mentioned) & $\begin{array}{l}\text { High (not } \\
\text { mentioned) }\end{array}$ & $\begin{array}{l}\text { High (not } \\
\text { mentioned) }\end{array}$ & 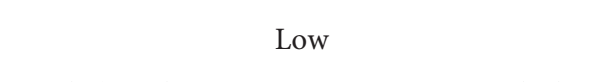 & Low \\
\hline $\begin{array}{l}\text { Rosaline et al. } \\
2013[14]\end{array}$ & $\begin{array}{l}\text { Unclear (teeth were } \\
\text { randomly divided) }\end{array}$ & $\begin{array}{l}\text { High (not } \\
\text { mentioned) }\end{array}$ & $\begin{array}{l}\text { High (not } \\
\text { mentioned) }\end{array}$ & $\begin{array}{l}\text { High (canal preparation not mentioned, the } \\
\text { volume of irrigant used not mentioned, and } \\
\text { the type of needle used not mentioned) }\end{array}$ & Low \\
\hline $\begin{array}{l}\text { Gupta-Wadhwa } \\
\text { et al. } 2016 \text { [15] }\end{array}$ & $\begin{array}{l}\text { Unclear (samples were } \\
\text { randomly divided) }\end{array}$ & $\begin{array}{l}\text { High (not } \\
\text { mentioned) }\end{array}$ & $\begin{array}{l}\text { High (not } \\
\text { mentioned) }\end{array}$ & 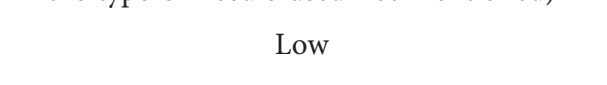 & Low \\
\hline $\begin{array}{l}\text { Sharifian et al. } \\
2009[16]\end{array}$ & $\begin{array}{l}\text { Unclear (samples were } \\
\text { randomly divided) }\end{array}$ & $\begin{array}{l}\text { High (not } \\
\text { mentioned) }\end{array}$ & $\begin{array}{l}\text { High (not } \\
\text { mentioned) }\end{array}$ & $\begin{array}{l}\text { High (irrigation protocol not mentioned, the } \\
\text { volume of irrigant and type of needle used not } \\
\text { mentioned) }\end{array}$ & Low \\
\hline $\begin{array}{l}\text { Divia et al. } 2018 \\
\text { [17] }\end{array}$ & High (not mentioned) & $\begin{array}{l}\text { High (not } \\
\text { mentioned) }\end{array}$ & $\begin{array}{l}\text { High (not } \\
\text { mentioned) }\end{array}$ & $\begin{array}{l}\text { High (irrigation protocol not mentioned, the } \\
\text { volume of irrigant, time of irrigation, type of } \\
\text { needle used, sample collection, and culture } \\
\text { medium were not mentioned) }\end{array}$ & High \\
\hline $\begin{array}{l}\text { Kumar et al. } 2018 \\
{[18]}\end{array}$ & High & $\begin{array}{l}\text { High (not } \\
\text { mentioned) }\end{array}$ & $\begin{array}{l}\text { High (not } \\
\text { mentioned) }\end{array}$ & Unclear (irrigation protocol not mentioned) & Low \\
\hline
\end{tabular}

contact time of the disinfectant, and the choice of the irrigant needle used for disinfection. Assessing the antimicrobial efficiency, eight out of nine studies showed a low risk of bias in reporting the outcome data $[5,11,16,18]$.
Studies have shown that nearly $70 \%$ of bacterial species invade the dentinal tubule, predominantly in apical periodontitis, discussing the microflora. The notable point was that more bacterial invasion was dominant in the coronal 
and middle third of the root canal system [23]. With the reduction in the oxygen potential in the apical third area, it creates a favourable environment for these organisms to establish and further colonize [24]. The virulence factors produced by these bacteria play a critical determinant role in the sustainability of these organisms [25]. Therefore, considering the abovementioned factors, the endodontic treatment should be carried out with the rationale of attaining the eradication of microbial species, although complete elimination is not possible [26].

Access cavity design plays an essential role in the disinfection of the root canal system. The cavity design should aim to provide straight-line access, facilitating the ease of instrumentation and allowing the irrigant flow to reach the working length [27]. The critical factor that plays a paramount role in conservative endodontic access is the incomplete elimination of necrotic tissue remnants. In such instances, the absolute eradication of microorganisms is absurd [28]. The previous study reported that even when a traditional endodontic access cavity was performed, the remaining pulp tissue was inevitable in the isthmus region [29]. Neelakantan et al. reported that complete debridement of the root canal was not achievable with contracted endodontic access as the entire pulp horn was not included in the cavity design, and deroofing of the pulp chamber was not performed [30].

Preparation of the root canal system is another crucial confounding factor. Preparation of the canal should be directed toward optimal in order to facilitate maximum disinfection [31]. Studies in literature have reported a larger preparation size with increased taper shown to exhibit better disinfection when compared to a lesser preparation size [32]. Maintaining the apical terminus diameter is a prime concern as the preparation taper and diameter of the apical terminus are interconnected [29]. It is noteworthy to mention that emphasize should be laid on circumventing overzealous preparation regarding respect for the canal morphology. Comparing the hand and rotary instruments, more uninstrumented areas were evident with hand instruments than with the rotary instruments for canal preparation [33, 34]. Apart from this, the instruments used for the canal preparation also play an essential role in accumulating dentinal mud into the apical ramification and lateral canal. It generally scraps more dentin when used with radial land and gets plugged into the isthmus, fins, and lateral canal. Therefore, the choice of canal preparation instruments should be considered as a contributing factor in attaining disinfection.

Over the years, the widely used agents for the disinfection of the root canal include sodium hypochlorite as the primary root canal irrigant and EDTA as a chelating agent. Sodium hypochlorite is a nonspecific proteolytic agent possessing antibacterial properties and dissolves the remnant pulp tissue [35]. Apart from this, it causes the dissolution of organic components of dentin. In an attempt to achieve the primary goal of eliminating the microorganisms, a higher concentration of sodium hypochlorite is used which can effectively eliminate microbes and indirectly affect the structural aspect of the root canal dentin. Due to the proteolytic action of $\mathrm{NaOCl}$ at a higher concentration, it promotes more removal of type 1 collagen, thus declining the tooth's strength when the contact time was more than 1 hour [36]. It is also evident that the concentration of the $\mathrm{NaOCl}$ influences the dissolving property. Periodic replenishment of $\mathrm{NaOCl}$ during instrumentation also plays a significant role in maintaining the concentration throughout the treatment procedure.

The contact time of the irrigant and its volume can be increased by lowering the concentration of $\mathrm{NaOCl}$ so as to reduce the cytotoxic effects. However, the studies have shown that a contact time of not less than 40 minutes with $5.25 \% \mathrm{NaOCl}$ showed to be more effective when compared to lesser concentration for the same period with frequent replenishment [20]. The authors strongly make a standpoint that studies must adhere to the standardized irrigation regimen when they comparatively evaluate the antibacterial activity of $\mathrm{NaOCl}$ with herbal agents. None of the studies included in the systematic review maintained the contact time of 40 minutes for $\mathrm{NaOCl}$. They concern herbal agents; there is no randomized clinical trial evidence to recommend contact time. There is no clear-cut recommendation exists regarding the volume of the irrigant. However, Zehnder suggested a beneficial role of copious amount of hypochlorite $[20,37]$.

It is a well-known fact that the needle's design and its insertion depth play a prime role in flow rate, which in turn influences the disinfection of the root canal system [38]. A 30 -gauge side-vented needle allows the operator to place it up to $1 \mathrm{~mm}$ short of working length without binding. It also facilitates the ease of back and forth movement in the canal in order to reduce the exerted apical pressure and prevent the vapor lock effect. Discussing fluid dynamics, another aspect that needs to be taken into consideration is the flow rate of the irrigant. The effective disinfection of the root canal is related to the flow rate of the irrigant. The confounding factor directly related to the flow rate depends on the intrabarrel pressure, operator fatigue, thumb control of the operator, and gender of the operator [39].

4.2. Quantitative Review. The present systematic review discussed the studies that compared hypochlorite with herbal agents on antimicrobial efficiency. Efforts are going on in the field of research to minimize the antimicrobial resistance developed using conventional chemical agents by investigating the efficiency of herbal agents to replace the existing gold-standard agents. The authors of this review put forth a standpoint on whether these agents can become an alternative for canal disinfection.

Studies' included in the current systematic review used various herbal agents as a root canal irrigant. They included herbal agents such as oregano extract, triphala, green tea polyphenol, Morinda citrifolia, neem, carvacrol, tulsi, Ocimum sanctum, Cinnamomum zeylanicum, Syzygium aromaticum, and Zataria multiflora.

Discussing the individual agents, among all the herbal agents used, triphala, green tea polyphenol, and Morinda citrifolia were used in 4 studies [11, 12, 14, 17]. From the 
abovementioned herbal agents, triphala was found to be the most effective antimicrobial agent, followed by green tea polyphenol, and Morinda citrifolia was found to be the least effective. The included studies which used oregano extract and neem showed conflicting results. Since different herbal agents were used in previous studies, there is no homogeneity of the variables in the included articles. Hence, it is impossible to conclude with a single herbal agent as an effective irrigant for canal disinfection. However, its antimicrobial activity was the least when compared with hypochlorite.

Previous studies have used different concentrations of hypochlorite. This variation could be a significant confounding factor in the outcome results, which should also be taken into consideration. Therefore, it is not possible to conclude that one herbal agent is a better alternative irrigant for smear layer removal as there are variables in the included studies.

4.3. Qualitative Review. Meta-analysis could not be performed due to the heterogeneity of the included articles and variation in the included studies.

4.4. Inference. The authors of this review infer that the herbal agents cannot be a substitute for hypochlorite concerning the antimicrobial properties. All the included studies in this review showed inferior antimicrobial efficacy of the herbal agents (triphala, green tea extract, Morinda citrifolia, neem, carvacrol, tulsi, Ocimum sanctum, Cinnamomum zeylanicum, and Syzygium aromaticum). Only oregano oil and Zataria multiflora showed similar antimicrobial efficiency as sodium hypochlorite $[5,13]$.

4.5. Future Inference. The present systematic review was at the in vitro level; therefore, the results cannot be translated into the exact clinical conditions. Studies should concentrate on the concentration, type, volume, and contact time of these herbal agents such that they can either be used as an alternative to minimize antimicrobial resistance or as an adjunct to the already existing conventional agents. Furthermore, future studies can concentrate on whether there is a difference in the efficiency of these herbal when used freshly after the extract preparation compared to stored extract. More clinical trials should be performed to uncover any precipitate formation using these agents when used in combination and to assess if any discoloration is observed.

\section{Conclusion}

Within the limitations of the study, taking into consideration various factors, herbal agents showed less efficiency than different concentrations of sodium hypochlorite regarding the antimicrobial property. The authors of this systematic review put forth the standpoint that though results do not translate the clinical scenario, they cannot furnish definitive evidence in reporting the outcome.
However, future studies can focus on the use of these herbal agents in attaining optimal disinfection.

\section{Data Availability}

The data set used in the current study will be made available at a reasonable request.

\section{Conflicts of Interest}

The authors declare that they have no conflicts of interest to report regarding the present study.

\section{References}

[1] J. F. Schirrmeister, A.-L. Liebenow, K. Pelz et al., "New bacterial compositions in root-filled teeth with periradicular lesions," Journal of Endodontics, vol. 35, no. 2, pp. 169-174, 2009.

[2] C. Stuart, S. Schwartz, T. Beeson, and C. Owatz, "Enterococcus faecalis: its role in root canal treatment failure and current concepts in retreatment," Journal of Endodontics, vol. 32, no. 2, pp. 93-98, 2006.

[3] Z. Metzger, M. Solomonov, and A. Kfir, "The role of mechanical instrumentation in the cleaning of root canals," Endodontic Topics, vol. 29, no. 1, pp. 87-109, 2013.

[4] S. Jaju and P. P. Jaju, "Newer root canal irrigants in horizon: a review," International Journal of Dentistry, vol. 2011, Article ID 851359, 9 pages, 2011.

[5] E. Ok, N. Adanir, and T. Ozturk, "Antibacterial and smear layer removal capability of oregano extract solution," European Journal of Dermatology, vol. 9, no. 1, pp. 20-24, 2015.

[6] P. Babaji, K. Jagtap, H. Lau, N. Bansal, S. Thajuraj, and P. Sondhi, "Comparative evaluation of antimicrobial effect of herbal root canal irrigants (Morinda citrifolia, Azadirachta indica, aloe vera) with sodium hypochlorite: an in vitro study," Journal of International Society of Preventive and Community Dentistry, vol. 6, no. 3, pp. 196-199, 2016.

[7] V. Panchal, D. Gurunathan, and N. Muralidharan, "Comparison of antibacterial efficacy of cinnamon extract, neem extract as irrigant and sodium hypochlorite against Enterococcus fecalis: an in vitro study," Indian Journal of Dental Research, vol. 31, no. 1, p. 124, 2020.

[8] H. A. K. Mavani, I. M. Tew, L. Wong et al., "Antimicrobial efficacy of fruit peels eco-enzyme against Enterococcus faecalis: an in vitro study," International Journal of Environmental Research and Public Health, vol. 17, no. 14, p. 5107, 2020.

[9] G. Nimbulkar, V. Garacha, V. Shetty et al., "Microbiological and clinical evaluation of neem gel and chlorhexidine gel on dental plaque and gingivitis in 20-30 years old adults: a randomized parallel-armed, double-blinded controlled trial," Journal of Pharmacy \& Bioallied Sciences, vol. 12, no. Suppl 1, pp. S345-S351, 2020.

[10] K. Janani, P. Ajitha, R. Sandhya, and K. V. Teja, "Chemical constituent, minimal inhibitory concentration, and antimicrobial efficiency of essential oil from oreganum vulgare against Enterococcus faecalis: an in vitro study," Journal of Conservative Dentistry, vol. 22, no. 6, pp. 538-543, 2019.

[11] M. Pujar, C. Patil, and A. Kadam, "Comparison of antimicrobial efficacy of Triphala, (GTP) green tea polyphenols and 3\% of sodium hypochlorite on Enterococcus faecalis biofilms formed on tooth substrate: in-vitro," Journal of Endodontics, vol. 3, no. 2, p. 7, 2011. 
[12] E. Choudhary, K. R. Indushekar, B. G. Saraf, N. Sheoran, D. Sardana, and A. Shekhar, "Exploring the role of Morinda citrifolia and Triphala juice in root canal irrigation: an ex vivo study," Journal of Conservative Dentistry, vol. 21, no. 4, pp. 443-449, 2018.

[13] M. Sedigh-Shams, P. Badiee, A. Adl, M. Sarab, A. Abbaszadegan, and M. Nabavizadeh, "In vitro comparison of antimicrobial effect of sodium hypochlorite solution and Zataria multiflora essential oil as irrigants in root canals contaminated with Candida albicans," Journal of Conservative Dentistry, vol. 19, no. 1, p. 101, 2016.

[14] H. Rosaline, D. Kandaswamy, D. Gogulnath, and M. Rubin, "Influence of various herbal irrigants as a final rinse on the adherence of Enterococcus faecalis by fluorescence confocal laser scanning microscope," Journal of Conservative Dentistry, vol. 16, no. 4, pp. 352-355, 2013.

[15] A. Gupta-Wadhwa, J. Wadhwa, and J. Duhan, "Comparative evaluation of antimicrobial efficacy of three herbal irrigants in reducing intracanal E. faecalis populations: an in-vitro study," Journal of Clinical and Experimental Dentistry, vol. 8, no. 3, pp. e230-e235, 2016.

[16] M. R. Sharifian, N. Shokouhinejad, M. Aligholi, M. Emaneini, and J. Alizadeh, "Antibacterial substantivity of carvacrol and sodium hypochlorite in infected bovine root dentin," Iranian Endodontic Journal, vol. 4, pp. 45-48, 2009.

[17] A. R. Divia, M. G. Nair, J. M. Varughese, and S. Kurien, “A comparative evaluation of Morinda citrifolia, green tea polyphenols, and Triphala with 5\% sodium hypochlorite as an endodontic irrigant against Enterococcus faecalis: an in vitro study," Dental Research Journal, vol. 15, no. 2, pp. 117-122, 2018.

[18] A. Arvind Kumar, A. S. Sarthaj, and S. M. Antony, "Comparative evaluation of antibacterial and layer removal efficacy of two different herbal irrigants-an in vitro study," International Healthcare Research Journal, vol. 1, no. 11, pp. 350-354, 2018.

[19] P. Neelakantan, H. M. A. Ahmed, M. C. M. Wong, J. P. Matinlinna, and G. S. P. Cheung, "Effect of root canal irrigation protocols on the dislocation resistance of mineral trioxide aggregate-based materials: a systematic review of laboratory studies," International Endodontic Journal, vol. 51, no. 8, pp. 847-861, 2018.

[20] M. Zehnder, "Root canal irrigants," Journal of Endodontics, vol. 32, no. 5, pp. 389-398, 2006.

[21] M. Haapasalo, U. Endal, H. Zandi, and J. M. Coil, "Eradication of endodontic infection by instrumentation and irrigation solutions," Endodontic Topics, vol. 10, no. 1, pp. 77-102, 2005.

[22] A. M. Alavi, A. Opasanon, Y.-L. Ng, and K. Gulabivala, "Root and canal morphology of Thai maxillary molars," International Endodontic Journal, vol. 35, no. 5, pp. 478-485, 2002.

[23] R. M. Love, "Regional variation in root dentinal tubule infection by Streptococcus gordonii," Journal of Endodontics, vol. 22, no. 6, pp. 290-293, 1996.

[24] W. J. Loesche, F. Gusberti, G. Mettraux, T. Higgins, and S. Syed, "Relationship between oxygen tension and subgingival bacterial flora in untreated human periodontal pockets," Infection and Immunity, vol. 42, no. 2, pp. 659-667, 1983.

[25] I. N. Rôças, J. F. Siqueira, M. C. Aboim, and A. S. Rosado, "Denaturing gradient gel electrophoresis analysis of bacterial communities associated with failed endodontic treatment," Oral Surgery, Oral Medicine, Oral Pathology, Oral Radiology, and Endodontics, vol. 98, no. 6, pp. 741-749, 2004.
[26] J. F. Siqueira and I. N. Rôças, "Clinical implications and microbiology of bacterial persistence after treatment procedures," Journal of Endodontics, vol. 34, no. 11, pp. 1291-1301, 2008.

[27] C. Ruddle, "Endodontic disinfection: tsunami irrigation," Saudi Endodontic Journal, vol. 5, no. 1, p. 1, 2015.

[28] G. Rover, F. G. Belladonna, E. A. Bortoluzzi, G. De-Deus, E. J. N. L. Silva, and C. S. Teixeira, "Influence of access cavity design on root canal detection, instrumentation efficacy, and fracture resistance assessed in maxillary molars," Journal of Endodontics, vol. 43, no. 10, pp. 1657-1662, 2017.

[29] L. Susin, Y. Liu, J. C. Yoon et al., "Canal and isthmus debridement efficacies of two irrigant agitation techniques in a closed system," International Endodontic Journal, vol. 43, no. 12, pp. 1077-1090, 2010.

[30] P. Neelakantan, K. Khan, G. P. Hei Ng, C. Y. Yip, C. Zhang, and G. S. Pan Cheung, "Does the orifice-directed dentin conservation access design debride pulp chamber and mesial root canal systems of mandibular molars similar to a traditional access design?" Journal of Endodontics, vol. 44, no. 2, pp. 274-279, 2018.

[31] P. Neelakantan, D. R. Herrera, V. G. A. Pecorari, and B. P. F. A. Gomes, "Endotoxin levels after chemomechanical preparation of root canals with sodium hypochlorite or chlorhexidine: a systematic review of clinical trials and metaanalysis," International Endodontic Journal, vol. 52, no. 1, pp. 19-27, 2019.

[32] A. Khademi, M. Yazdizadeh, and M. Feizianfard, "Determination of the minimum instrumentation size for penetration of irrigants to the apical third of root canal systems," Journal of Endodontics, vol. 32, no. 5, pp. 417-420, 2006.

[33] M.-K. Wu, P. R. Wesselink, and R. E. Walton, "Apical terminus location of root canal treatment procedures," Oral Surgery, Oral Medicine, Oral Pathology, Oral Radiology \& Endodontics, vol. 89, no. 1, pp. 99-103, 2000.

[34] O. Peters, "Current challenges and concepts in the preparation of root canal systems: a review," Journal of Endodontics, vol. 30, no. 8, pp. 559-567, 2004.

[35] A. Byström and G. Sundqvist, "Bacteriologic evaluation of the effect of 0.5 percent sodium hypochlorite in endodontic therapy," Oral Surgery, Oral Medicine, and Oral Pathology, vol. 55, no. 3, pp. 307-312, 1983.

[36] P. Ohara, M. Torabinejad, and J. D. Kettering, “Antibacterial effects of various endodontic irrigants on selected anaerobic bacteria," Dental Traumatology, vol. 9, no. 3, pp. 95-100, 1993.

[37] B. Retamozo, S. Shabahang, N. Johnson, R. M. Aprecio, and M. Torabinejad, "Minimum contact time and concentration of sodium hypochlorite required to eliminate Enterococcus faecalis," Journal of Endodontics, vol. 36, no. 3, pp. 520-523, 2010.

[38] C. Boutsioukis, B. Verhaagen, M. Versluis, E. Kastrinakis, P. R. Wesselink, and L. W. M. van der Sluis, "Evaluation of irrigant flow in the root canal using different needle types by an unsteady computational fluid dynamics model," Journal of Endodontics, vol. 36, no. 5, pp. 875-879, 2010.

[39] C. Boutsioukis, T. Lambrianidis, E. Kastrinakis, and P. Bekiaroglou, "Measurement of pressure and flow rates during irrigation of a root canal ex vivo with three endodontic needles," International Endodontic Journal, vol. 40, no. 7, pp. 504-513, 2007. 